\title{
EFFECT OF MICROPLASTIC ON GREEN MUSSEL Perna viridis: EXPERIMENTAL APPROACH
}

\author{
Nur Fadhilah Rahim ${ }^{1}$, Khusnul Yaqin ${ }^{2}$, Nita Rukminasari ${ }^{3}$ \\ Submitted: November 5, 2019, Accepted: December 12, 2019
}

\author{
1,2,3 Department of Fisheries, Faculty of Marine Science and Fisheries, University of Hasanuddin \\ Jl. Perintis Kemerdekaan, Km. 10, Makassar, Indonesia 90245 \\ Corresponding Author; \\ Khusnul Yaqin \\ Email: khusnul@gmail.com
}

\begin{abstract}
Plastics become debris in the ocean that can be broken down into tiny particles of micro size $(<5 \mathrm{~mm})$ and scattered into columns to the bottom of the water. Its very small size makes it easily accessible to various aquatic organisms, such as plankton, crustacean, and mussel. There have been many studies use mussel as a bioindicator for microplastic pollution but no one has observed the effect of microplastic exposure to mussel mortality. The aim of study was to examine the effect of microplastic on mussel mortality. Green mussels were collected from Mandalle Waters, Pangkep Regency (Pangkajene Kepualauan) then were exposed to microplastic polyethylene originating from shieving of scrub soap. The exposure was carried out for 7 days with microplastic concentrations of 0.05 (A), 0.5 (B), and 5 (C) g/L. Statistical test results showed the treatment B and C were not significantly different, but the two treatment were significantly different from treatment A. The percentage of green mussel mortality during the experiment increased with increasing microplastic concentrations with the percentage of mortality exceeding $80 \%$ at treatment $\mathrm{C}$.
\end{abstract}

Keywords: Green mussel, microplastic concentration, mortality of green mussel

\section{INTRODUCTION}

Since plastic production in the 1950s until 2017, the amount of plastic waste has reached 348 million tons (Plastic - the Facts, 2018) and become debris in the ocean (Gewert et al., 2015; Moore, 2008). This plastic waste can break into very small micro-sized particles $(<5 \mathrm{~mm})$ (Dehaut et al., 2016; Depledge et al., 2013; Wagner et al., 2014; Willis et al., 2017). Microplastics spread into the column to the bottom of the water (Eriksen et al., 2014). Microplastics in the waters come from soap and washing clothes, (primary sources), and degradation of large plastics into small plastics (secondary sources) (Anbumani \& Kakkar 2018; Anderson et al., 2015; Boucher \& Friot, 2017). Plastic degradation in waters becomes microplastic due to the effect of UV radiation, wind, currents, waves and tides (Galloway et al., 2017; Lee et al., 2013).

This microplastic becomes dangerous because of its very small size so that was easily consumed by various aquatic organisms, such as zooplankton (Cole et al., 2013), mussel (Wegner et al., 2012), to Echinoderm (Graham \& Thompson, 2009). In addition, microplastic accumulation can occur through trophic transfer from contaminated prey (Nelms et al., 2018; Wright et al., 2013) then accumulation of microplastic occurs at the highest trophic level (Fossi et al., 2012).

Mussels become a bioindicator for microplastic pollution because of their widely distributed, easy accumulated of microplastics, and are closely related to the food chain (Li et al., 2019a). Mussels are filter feeder organisms which in their feeding process can accumulate microplastic (Sussarellu et al., 2016). When microplastics in seawater meet the surface of the gills, they can be captured and trapped into mucus and then assimilated with the gill epithelium or transported into the mouth and digestive system (Bråte et al., 2018; Kolandhasamy et al., 2018). Furthermore, the particles will negatively impact the health of mussels (von Moos et al., 2012).

Some researchers have made observations to analyze the presence and effect of miroplastik on several types of mussels. Intake and accumulation of microplastics are demonstrated by various filter feeder such as Mytilus edulis (Browne et al., 2008; Van Cauwenberghe et al., 2015; Kolandhasamy et al., 2018; von Moos et al., 2012; Porter et al., 2018; Qu et al., 2018; Ward \& Kach, 2009; Wegner et al., 2012), Mytilus galloprovincialis (Bonello et al., 2018; Li et al., 2015; Renzi et al., 2018; Vandermeersch et al., 2015), Modiolus modiolus (Catarino et al., 2018), Perna perna (Santana et al., 2016), and Perna viridis (Khoironi et al., 2018).

Some researchers also observed microplastic accumulation in mussels exposed to various types, sizes, shapes, and concentrations. Mussels are able to accumulate microplastics with different amounts of accumulation in each tissue (Van 
Cauwenberghe et al., 2015; Kolandhasamy et al., 2018; Qu et al., 2018).

In addition to absorption, microplastic accumulation also occurs through attachment to the foot of mussel. Kolandhasamy et al. (2018) found a high number of microplastics in the foot of M. edulis about $42-59 \%$ of the total microplastics in all other tissues. Microplatics can also be accumulated by mussels through the process of fusion with byssus ( $\mathrm{Li}$ et al., 2019b).

Based on the above information, there was lack of study to observed the effect of microplastic exposure to the mortality of green mussels Perna viridis. Therefore this paper will discuss the results of research on the effects of microplastic on the mortality of green mussels.

\section{MATERIALS AND METHODS}

\section{Microplastic (MP)}

The microplastic used was a type of polyethylene derived from the shieving of scrub soap. The scrub was dissolved in water, then filtered using filter size $0.075,0.125$, and $0.180 \mathrm{~mm}$ arranged in sequence with the lowest size at the bottom. The results were transferred into a petri dish to be heated in an oven at $90^{\circ} \mathrm{C}$ for 48 hours (Figure 1).

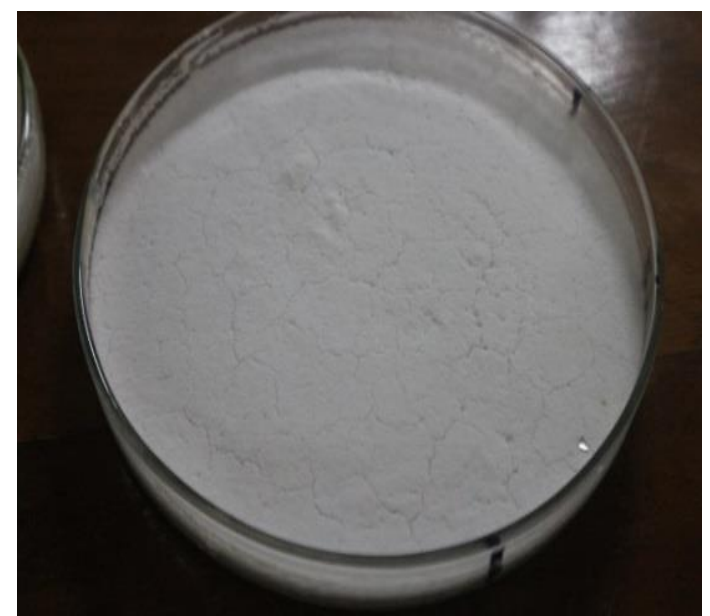

Picture 1. Polyethylene microplastic from the dried scrub soap

\section{Sample Collection}

Green mussels with size of $5.1-6.0 \mathrm{~cm}$ were collected from Mandalle Waters, Pangkep Regency (Pangkajene Kepualauan) by using hand. Length of mussel shell was measured using a digital caliper. The mussels were acclimatized for 14 days (Rist et al., 2016) in the aquarium before being used in the experiment. During the acclimatization period, green mussels were given algae (Spirulina sp) $1.2 \mathrm{~g} / \mathrm{L}$.

\section{Microplastic Exposure}

Twelve green mussels for each treatment were put into a 7 liter jar containing 5 liters of sea water. After that the sample was exposured for 7 days (Paul-Pont et al., 2016) with pollutants, that are microplastics which had been mixed with Spirulina sp. and starch. The concentration of pollutants used were 0.05 (A), 0.5 (B), and 5 (C) $\mathrm{g} / \mathrm{L}$ (Santana et al., 2017). Inside $0.1 \mathrm{~g}$ of pollutant there are $3309 \pm 239.4$ microplastic particles.

During the experiment, the media water was changed every day (Pittura et al., 2018). This was done to ensure that the material that has been removed by the mussel was not swallowed again (Van Cauwenberghe \& Janssen, 2014). Before replacing the water, measurements of water quality ( $\mathrm{pH}$, temperature, DO, and salinity) were measured. The aquarium was given aeration during the exposure process to maintain the oxygen concentration needed by green mussels.

\section{Microplastic Analysis}

The shell was opened and a meat sample from each mussel was put into each sample bottle. A $10 \% \mathrm{KOH}$ solution was added to each sample bottle with a concentration of 3 times the weight of the meat (Rochman et al., 2015) to digest the organic material and left for 7 days. Subsequently the samples were filtered using $0.45 \mu \mathrm{m}$ sterile membrane filter paper then placed into clean petri dishes for further analysis under a stereo microscope.

\section{Statistical Analysis}

Parametric anova was used to analyze the differences in microplastic accumulation and the percentage of mortality in each range of microplastic concentrations.

\section{RESULTS AND DISCUSSION}

\section{Results}

Statistical results showed that there were significant differences in the amount of microplastic accumulation between treatment $\mathrm{A}$ and $\mathrm{B}$, likewise between treatment $\mathrm{A}$ and $\mathrm{C}$. However there was no significant difference in the amount of microplastic accumulation between treatment B and C (Figure 2). The percentage of green mussel mortality during the experiment increased with increasing microplastic concentrations. In the control treatment, percentage of mortality was $5.53 \%$, then the percentage of mortality increased at treatment A by $30.57 \%$, treatment $\mathrm{B}$ by $50 \%$, while the 
percentage of mortality exceeded $80 \%$ at treatment C (Figure 3).

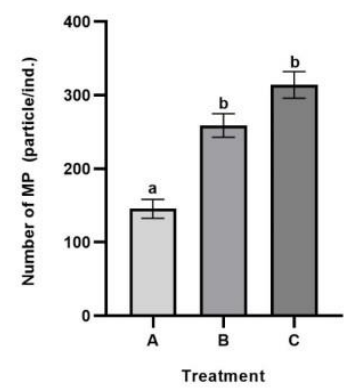

Picture 2. Number of microplastic particles in the body of green mussels at each treatment

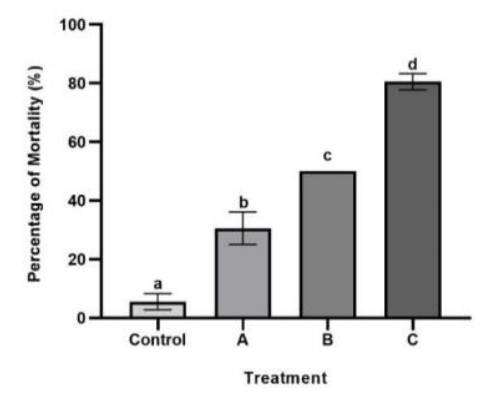

Picture 3. Percentage of mortality of green mussels at each treatment.

\section{DISCUSSION}

Research on the existence of microplastic in mussel has been carried out both field and laboratory research (Avio et al., 2015; Bråte et al., 2018; Browne et al., 2008; Van Cauwenberghe et al., 2015; Kolandhasamy et al., 2018; Magni et al., 2018; von Moos et al., 2012; Paul-Pont et al., 2016; Qu et al., 2018; Woods et al., 2018). In laboratory-based studies, each researcher used varies microplastic pollutant according to the size, shape, and type of polymer. In this study the microplastic used as a pollutant comes from a scrub soap containing microplastic granules with a type of polyethylene. As Carr et al. (2016) mentioned beauty products contained microplastics and Lei et al. (2017) mentioned in these products generally contain polyethylene.

Tested mussel after exposure by microplastic for 7 days, it was found that the highest amount of microplastic in green mussels were exposed to the highest treatment $(\mathrm{C})$. As the research conducted by Qu et al. (2018) and Setälä et al. (2015) which showed the number of microplastics in mussel was significantly higher at a high concentration treatments than at low concentration treatments.

The results of statistical tests between treatments, found that the treatment $\mathrm{B}$ and $\mathrm{C}$ were not significantly different of microplastic number in the mussel (Figure 2). The two treatments were significantly different from treatment A. This finding indicated that mussels have an ability to minimize the danger posed by something they filtered. Because the microplastics present in the treatment media water $\mathrm{B}$ were considered hazardous, the mussels re-emerge through the exhalant channel in the form of pseudofaeces. Li et al. (2019) mentioned that mussel could distinguish unwanted particles and will dispose of them in the form of pseudofeses as a way to defend themselves against a high amount of unwanted particle in their body.

Microplastics as pollutants are synthetic polymers (Bouwmeester et al., 2015) derived from fossil oil and gas (Hopewell et al., 2009) which contain carbon, hydrogen and oxygen, as they are also contained in fats in the tissues of organism. Therefore microplastic can bind to fat (lipophilic) in body tissue and cause body tissue to change or damage. Avio et al. (2015) and von Moos et al. (2012) mentioned microplastic exposure can affect to tissue of mussel and Van Cauwenberghe et al. (2015) mentioned this could pose severe health risks for the organism.

Increased microplastic concentrations were accompanied by an increase in the percentage of green mussel mortality (Figure 3). Galloway and Lewis (2016) revealed that the consumption of microplastic caused disruption in organs of organisms to death. Microplastic could accumulate in the organ (Kolandhasamy et al. 2018) and caused damage to tissues from the organ (Avio et al. 2015; von Moos et al. 2012), such as gills and hepatopancreas. Both organs have an important role in the process of taking, absorbing, and digesting food ( $\mathrm{Au}$ 2004). Therefore, if the gills and hepatopancreas were damaged and unable to carry out their roles as they should, then the function of other organs will be disrupted to cause death.

\section{CONCLUSION}

Mussel which has been exposed by varying concentration over 7 days causes mortality up to $80 \%$ at the highest microplastic concentration treatment. This mortality due to the damage of mussel organs, consequently it could not be function properly.

\section{REFERENCES}

Anbumani, S., Kakkar, P. 2018. Ecotoxicological effects of microplastics on biota: A review. Environmental Science and Pollution Research 25: 14373-14396. 
Anderson, A., Andrady, A., Arthur, C., Baker, J., Bouwman, H., Gall, S., Hidalgo-Ruz, V., Köhler, A., Law, K. L., Leslie, H., Kershaw, P., Pahl, S., Potemra, J., Ryan, P., Shim, W.J., Thompson, R., Takada, H., Turra, H., Vethaak, D., Wyles, K. 2015. Sources, fate and effects of microplastics in the marine environment: A global assessment. Gesamp Reports and Studies 90: $96 \mathrm{p}$.

Au, D.W. T. 2004. The application of histocytopathological biomarkers in marine pollution monitoring: A review. Marine Pollution Bulletin 48: 817-834.

Avio, C.G., Gorbi, S., Milan, M., Benedetti, M., Fattorini, D., d'Errico, G., Pauletto, M., Bargelloni, L., Regoli, F. 2015. Pollutants bioavailability and toxicology risk from microplastics to marine mussels. Environmental Pollution 198: 211 - 222.

Bonello, G., Varrella, P., Pane, L. 2018. First evaluation of microplastic content in benthic filter-feeders of the Gulf of $\mathrm{La}$ Spezia (Ligurian Sea). Aquatic Food Product Technology 27: $284-291$.

Bouwmeester, H., Hollman, P.C.H., Peters, R.J.B. 2015. Potential health impact of environmentally released micro- and nanoplastics in the human food production chain: experiences from nanotoxicology. Environmental Science and Technology 49: $8932-8947$.

Boucher, J., Friot, D. 2017. Primary microplastics in the oceans: A global evaluation of sources. IUCN, Gland, Switzerland.

Brate, I.L.N., Blazquez, M., Brooks, S.J., Thomas, K.V. 2018. Weathering impacts the uptake of polyethylene microparticles from toothpaste in Mediterranean mussels $(M$. galloprovincialis). Science of the Total Environment 626: 1310 - 1318.

Browne, M.A., Dissanayake, A., Galloway, T.S., Lowe, D.M., Thompson, R.C. 2008 Ingested microscopic plastic translocates to the circulatory system of the mussel, Mytilus edulis (L.). Environmental Science and Technology 42: 5026 - 5031.

Carr, S.A., Liu, J., Tesoro, A.G. 2016. Transport and fate of microplastic particles in wastewater treatment plants. Water Research 91: 174 - 182.

Catarino, A.I., Macchia, V., Sanderson, W.G., Thompson, R.C., Henry, T.B. 2018. Low levels of microplastics (MP) in wild mussels indicate that MP ingestion by humans is minimal compared to exposure via household fibers fallout during a meal. Environmental Pollution 237: 675 - 684.

Cole, M., Lindeque, P., Fileman, E., Halsband, C., Goodhead, R., Moger, J., Galloway, T.S. 2013. Microplastic ingestion by zooplankton. Environmental Science \& Technology 47: 6646 - 6655 .

Dehaut, A., Cassone, A., Frere, L., Hermabessiere, L., Himber, C., Rinnert, E., Riviere, G., Lambert, C., Soudant, P., Huvet, A., Duflos, G., Paul-Pont, I. 2016. Microplastics in seafood: Benchmark protocol for their extraction and characterization. Environmental Pollution 215: $223-233$

Depledge, M.H., Galgani, F., Panti, C., Caliani, I., Casini, S., Fossi, M.C. Plastic litter in the sea. Marine Environmental Research 92: $279-281$

Eriksen, M., Lebreton, L.C.M., Carson, H.S., Thiel, M., Moore, C.J., Borerro, J.C., Galgani, F., Ryan, P.G., Reisser, J. 2014. Plastic pollution in the world's oceans: More than 5 trillion plastic pieces weighing over 250.000 tons afloat at sea. Plos One 9: $1-15$.

Fossi, M.C., Panti, C., Guerranti, C., Coppola, D., Giannetti, M., Marsili, L., Minutoli, R. 2012. Are baleen whales exposed to the threat of microplastics? A case study of the Mediterranean fin whale (Balaenoptera physalus). Marine Pollution Bulletin 64: $2374-2379$.

Galloway, T.S., Lewis, C.N. 2016. Marine microplastics spell big problems for future generations. Proceedings of the National Academy of Sciences 113: 2331-2333.

Galloway, T.S., Cole, M., Lewis, C. 2017. Interactions of microplastic debris throughout the marine ecosystem. Nature Ecology \& Evolution 1: 1 - 5 .

Gewert, B., Plassmann, M.M., Macleod, M. 2015. Pathways for degradation of plastic polymers floating in the marine environment. Environmental Sciences: Processes and Impacts 17: 1513 - 1521.

Graham, E.R., Thompson, J.T. 2009. Deposit- and suspension-feeding sea cucumbers (Echinodermata) ingest plastic fragments. 
Experimental Marine Biology and Ecology 368: $22-29$

Hopewell, J., Dvorak, R., Kosior, E. 2009. Plastics recycling: challenges and opportunities. Philosophical Transactions of the Royal Society B: Biological Sciences 364: 2115 2126.

Khoironi, A., Anggoro, S., Sudarno. 2018. The existence of microplastic in Asian green mussels. IOP Conference Series: Earth and Environmental Science 131: $1-6$

Kolandhasamy, P., Su, L., Li, J., Qu, X., Jabeen, K., Shi, H. 2018. Adherence of microplastics to soft tissue of mussels: A novel way to uptake microplastics beyond ingestion. Science of the Total Environment $610-611: 635-640$.

Lee, J., Hing, S., Song, Y.K., Hong, S.H., Jang, Y.C., Jang, M., Heo, N.W., Han, G.M., Lee, M.J., Kang, D., Shim, W.J. 2013. Relationships among the abundances of plastic debris in different size classes on beaches in South Korea. Marine Pollution Bulletin 77: 349 - 354

Lei, K., Qiao, F., Liu, Q., Wei, Z., Qi, H., Cui, S., Yue, X., Deng, Y. 2017. Microplastics releasing from personal care and cosmetic products in China. Marine Pollution Bulletin 123: 122 - 126 .

Li, J., Yang, D., Li, L., Jabeen, K., Shi, H. 2015. Microplastics in commercial bivalves from China. Environmental Pollution 207: 190 195.

Li, J., Lusher, A.L., Rotchell, J.M., Deudero, S., Turra, A., Brate, I.L.N., Sun, C., Hossain, M.S., Li, Q., Kolandhasamy, P., Shi, H. 2019a. Using mussel as a global bioindicator of coastal microplastic pollution. Environmental Pollution 244: $522-533$

Li, Q., Sun, C., Wang, Y., Cai, H., Li, L., Li, J., Shi, H.. 2019b. Fusion of microplastics into the mussel byssus. Environmental Pollution 252: $420-426$.

Magni, S., Gagne, F., Andre, C., Torre, C.D., Auclair, J., Hanana, H., Parenti, C.C., Bonasoro, F., Binelli, A. 2018. Evaluation of uptake and chronic toxicity of virgin polystyrene microbeads in freshwater zebra mussel Dreissena polymorpha (Mollusca: Bivalvia). Science of the Total Environment $631-632: 778-788$.
Mateo, D.R., MacCallum, G.S., Davidson, J. 2015. Field and laboratory transmission studies of haemic neoplasia in the soft-shell clam, Mya arenaria, from Atlantic Canada. Journal of Fish Diseases 39: 913 - 927.

Moore, C.J. 2008. Synthetic polymers in the marine environment: A rapidly increasing, long-term threat. Environmental Research 108: $131-139$

Nelms, S.E., Galloway, T.S., Godley, B.J., Jarvis, D.S., Lindeque, P.K. 2018. Investigating microplastic trophic transfer in marine top predators. Environmental Pollution 238: $999-1007$.

Paul-Pont, I., Lacroix, C., Fernandez, C.G., Hegaret, H., Lambert, C., Le Goic, N., Frere, L., Cassone, A.L., Sussarellu, R., Fabioux, C., Guyomarch, J. 2016. Exposure of marine mussels Mytilus spp. to polystyrene microplastics: toxicity and influence of fluoranthene bioaccumulation. Environmetal Pollution 216: 724 - 737.

Pittura, L., Avio, C.G., Giuliani, M.E., d'Errico, G., Keiter, S.H., Cormier, B., Gorbi, S., Regoli, F. 2018. Microplastics as vehicles of environmental pahs to marine organisms: combined chemical and physical hazards to the mediterranean mussels, Mytilus galloprovincialis. Frontiers in Marine Science 5: $1-15$

Plastic- the Facts 2018. An analysis of European plastics production, demand and waste. https://www.plasticseurope.org/application/ files/6315/4510/9658/Plastics the facts 20 18 AF web.pdf.

Porter, A., Lyons, B.P., Galloway, T.S., Lewis, C.N. 2018. The role of marine snows in microplastic fate and bioavailability. Environmental Science \& Technology 12: $7111-7119$.

Prato, E., Biandolino, F., Scardicchio, C. 2006. Test for acute toxicity of copper, cadmium, and mercury in five marine species. Turkish Journal of Zoology 30: 285 - 290.

Qu, X., Su, L., Li, H., Liang, M., Shi, H. 2018. Assessing the relationship between the abundance and properties of microplastics in water and in mussels. Science of the Total Environment 621: $679-689$.

Renzi, M., Guerranti, C., Blaskovic, A. 2018. Microplastic contents from maricultured and natural mussels. Marine Pollution Bulletin 131: 248 - 251 . 
Rist, S.E., Assidqi, K., Zamani, N.P., Appel, D., Perschke, M., Huhn, M., Lenz, M. 2016. Suspended micro-sized PVC particles impair the performance and decrease survival in the Asian green mussel Perna viridis. Marine Pollution 111: 213 - 220.

Rochman, C.M., Tahir, A., Williams, S.L., Baxa, D.V., Lam, R., Miller, J.T., Teh, F.C., Werorilangi, S., Teh, S.J. 2015. Anthropogenic debris in seafood: Plastic debris and fibers from textiles in fish and bivalves sold for human consumption. Scientific Reports 5: 1 - 10.

Santana, M.F.M., Ascer, L.G., Custodio, M.R., Moreira, F.T., Turra, A. 2016. Microplastic contamination in natural mussel beds from a Brazilian urbanized coastal region: Rapid evaluation through bioassessment. Marine Pollution Bulletin 106: 183 - 189.

Santana, M.F.M., Moreira, F.T., Turra, M.A. 2017. Trophic transference of microplastics under a low exposure scenario: Insights on the likelihood of particle cascading along marine food-webs. Marine Pollution Bulletin 121: 154 - 159 .

Setälä, O., Norkko, J., Lehtiniemi, M. 2015. Feeding type affects microplastic ingestion in a coastal invertebrate community. Marine Pollution Bulletin 102: 95 - 101

Sussarellu, R., Suquet, M., Thomas, Y., Lambert, C., Fabioux, C., Pernet, M.E.J., Goic, N.L., Quillien, V., Mingant, C., Epelboin, Y., Corporeau, C., Guyomarch, J., Robbens, J., Paul-pont, I., Soudant, P., Huvet, A. 2016. Oyster reproduction is affected by exposure to polystyrene microplastics. Proceedings of the National Academy of Science 113: $2430-2435$.

Van Cauwenberghe, L., Janssen, C.G. 2014. Microplastics in bivalves cultured for human consumption. Environmental Pollution 193: $65-70$.

Van Cauwenberghe, L., Claessens, M., Vandegehuchte, M.B. 2015. Microplastics are taken up by mussels (Mytilus edulis) and lugworms (Arenicola marina) living in natural habitats. Environmetal Pollution 199: $10-17$.
Vandermeersch, G., Van Cauwenberghe, L., Janssen, C.R., Marques, A., Granby, K., Gabriella, F., Kotterman, M.J.J., Diogene, J., Bekaert, K., Robbens, J., Devriese, L. 2015. A critical view on microplastic quantification in aquatic organisms. Environmetal Research 143: 46 - 55.

Von Moos, N., Burkhardt-Holm, P., Kohler, A. 2012. Uptake and effects of microplastics on cells and tissue of the blue mussel Mytilus edulis L. after an experimental exposure. Environmental Science and Technology 46: 11327 - 11335.

Wagner, M., Scherer, C., Alvarez-Munoz, D., Brennholt, N., Bourrain, X., Buchinger, S., Fries, E., Grosbois, C., Klasmeier, J., Marti, T., Rodriguez-Mozaz, S., Urbatzka,R., Vethaak, A.D., Winther-Lielsen, M., Reifferscheid, G. 2014. Microplastics in freshwater ecosystems: what we know and what we need to know. Environmental Science Europe 26: $1-9$.

Ward, J.E., Kach, D.J. 2009. Marine aggregates facilitate ingestion of nanoparticles by suspension-feeding bivalves. Marine Environmental Research 68: 137 - 142.

Wegner, A., Besseling, E., Foekema, E.M., Kamermans, P., Koelmans, A.A. 2012. Effects of nanopolystyrene on the feeding behavior of the blue mussel (Mytilus edulis). Environmental Toxicology \& Chemistry $31: 1-7$.

Willis, K.A., Eriksen, R., Wilcox, C., Hardesty, B.D. 2017. Microplastic distribution at different sediment depths in an Urban Estuary. Frontiers in Marine Science 4:1-8.

Woods, M.N., Stack, M.E., Fields, D.M., Shaw, S.D., Matrai, P.A. 2018. Microplastic fiber uptake, ingestion, and egestion rates in the blue mussel (Mytilus edulis). Marine Pollution Bulletin 137: 638 - 645.

Wright, S.L., Thompson, R.C., Galloway, T.S. 2013. The physical impacts of microplastics on marine organisms: A review. Environmental Pollution 178: 483 - 492. 